\title{
Sobre a psicoterapia ${ }^{1,2}$
}

\section{Ludwig Binswanger}

\section{Possibilidade e realidade da ação psicoterapêutica}

Um dia, durante uma conferência, perguntamos à platéia o seguinte: "O que vocês esperam, primordialmente, de uma conferência sobre a psicoterapia?” e os jovens suíços, estudantes de medicina, de nosso auditório responderam sem hesitação alguma: “Explique-nos como a psicoterapia pode agir?”. Podemos admitir igualmente que alguns dentre vocês, leitores, colocaramse esta questão e esperam uma resposta. Para o jovem estudante de medicina, uma significação completamente nova aparece quando ele ouve falar de um exercício médico para o qual não deve utilizar nem mão, nem instrumento ou medicamento, nem luz, água ou ar, assim como também não deve lançar mão de eletricidade, calor ou frio, mas apenas do discurso humano, das palavras e de todos os outros meios pelos quais o homem pode entrar em contato com o homem e agir sobre ele.

1. Tradução de Monica Seincman.

2. As idéias desenvolvidas neste ensaio devem ser relacionadas com os seguintes trabalhos do autor: 1. Fonction vitale et histoire intérieure de la vie; 2. Le rêve et l'existence; 3. Geschehnis und Erlebnis; 4. Das Raumproblem in der psychopathologie; 5. Über Ideenflucht; ver igualmente Psychotherapie als Beruf; Erfahren, Verstehen, Deuten in der Psychoanalyse e Psychoanal. Almanach. 
Se, com a pergunta "como pode agir a psicoterapia?”, você quiser perceber algo da própria coisa e não um simples slogan no sentido dos dogmas teóricos de alguma escola de psicoterapia e se não quiser se contentar com uma simples casuística, pedir-lhe-emos primeiramente para considerar que nada poderemos fazer para a compreensibilidade dos fatos científicos se não especificarmos, esclarecermos e controlarmos o alcance e o sentido das palavras e formas que utilizamos para descrevê-los e transcrevê-los. Pedimos, portanto, ao leitor, para não encarar nossa exposição como algo extremamente meticuloso, mas sim como uma tentativa das mais sérias de lhe expor o motivo de nosso tema, e isto da forma mais enérgica possível.

A palavra psicoterapia é uma expressão técnica (Kunstausdruck). Como qualquer neologismo científico, sua criação e sentido são devidos a uma escolha, abstratamente feita, de objetivos bem precisos, aqui de objetivos relativos ao conhecimento e resultados da psiquiatria clínica, referindo-se a uma certa esfera do ser. A esfera em questão é a do ser em uma intersubjetividade, em uma relação justa com o semelhante ou a do ser com o mundo comunitário (Mitwelt). Em todas as formas de psicoterapia médica, dois humanos ficam face a face, dois humanos, de um modo ou de outro, "relacionam-se um com o outro em uma recíproca dependência”, dois homens, de um modo ou de outro, "explicam-se um ao outro".

$\mathrm{Na}$ expressão psicoterapia, esta relação do ser humano em-uma-reciprocidade-com-o-semelhante é triplamente simplificada ou "reduzida": em primeiro lugar, quando, em vez de um dos dois parceiros, o doente, ela se refere somente a uma simples abstração científica, aqui “a psique”, e o outro parceiro, o médico, desaparece completamente por trás de sua função de próximo, a terapia; em segundo, porque, em suma, esta somente consegue formular uma direção de relação, indo do sujeito que assume a função terapêutica, o médico, à psique do doente e não do doente ao médico; finalmente, em terceiro, porque o confronto entre médico e doente não se expressa como uma relação com o próximo (de próximo a próximo), mas como um serviço prestado a uma causa. Pois, no sentido médico e psiquiátrico, em nenhuma circunstância psique significa o próximo = uma pessoa, nem mesmo o sujeito psicológico, mas o objeto "animado" (beseelt), o organismo animado, a unidade de função animada, o conceito de função vital psíquica etc.; $\theta \varepsilon \rho \alpha \pi \varepsilon i \alpha$ no sentido médico do termo, em contrapartida, significa a atenção, o cuidado, o encarregar-se, o tratamento, como fazer com que um outro organismo, um animal ou uma planta tire proveito disso, em suma, um serviço de cuidados ou intervenções benévolas junto a um objeto de cuidado. Literalmente traduzido, a expressão psicoterapia médica significa, portanto: serviço médico prestado à alma (Seele) de um próximo (alma sendo pensada como quintessência das funções vitais psíquicas). Se limitamo-nos a esta concepção da psicoterapia, como ela o diz a partir da própria palavra, ou seja, a partir da redução do sentido do ser, como 
próximo, à significação de intervenções benéficas psiquiátrico-médicas “unilaterais”, jamais poderíamos compreender e nos colocar de acordo em relação à questão: “Como a psicoterapia pode agir?”, pois a psicoterapia médica não cria, de forma alguma, novas forças, assim como não o faz a medicina somática; pelo contrário, da mesma forma como esta pode apenas isolar, concentrar e dirigir as forças que reinam no universo ou no cosmos anorgânico e orgânico, também a psicoterapia pode apenas isolar, concentrar e dirigir as "forças" que reinam no cosmos do ser como próximo, do ser humano com e para um próximo. Pedimos ao leitor manter claramente no espírito que ambas as esferas do ser (cosmos orgânico e anorgânico e cosmos do ser com e para um próximo) são primordiais, assim como são "forças elementares”. Em todos os campos da medicina, lidamos com estas duas forças elementares e a ela temos de retornar, mas é tudo; com efeito, a significação destas forças, elas próprias no universo inteiro em si e para si, e sua relação recíproca não são mais, então, da competência do problema médico. Hipócrates formulou claramente assim a conclusão última da sabedoria médica: "Os médicos inclinam-se ante os deuses, porque não há na arte médica força extraordinária alguma”.

A questão aparentemente tão clara: "Como, afinal, a psicoterapia pode agir?” é, na realidade, como o próprio leitor já deve ter percebido, essencialmente ambígua: por um lado, a questão quer dizer: como é possível, no final das contas, que a psicoterapia possa agir? Certamente, era isso que nossos jovens amigos solicitavam quando nos fizeram a pergunta. Por outro, ela quer dizer: de que maneira a psicoterapia pode realmente agir? Em outras palavras: como a psicoterapia obtém o efeito terapêutico em um caso concreto? É fácil ver que estas questões estão imediatamente conectadas àquela colocada aos limites da psicoterapia, mas não entraremos em detalhes, pois a resposta a esta questão decorre naturalmente das duas outras. O leitor terá, imediatamente, nossa resposta à primeira destas perguntas, e como elas dependem estreitamente uma da outra, não é desejável respondê-la senão em consideração a esta própria relação. Esta resposta é: é possível que a psicoterapia aja apenas porque ela representa uma certa parte do campo das ações que os homens exercem uns sobre os outros em todos os lugares e desde sempre; pouco importa que esta ação seja entorpecedora pela sugestão, estimulante pela educação ou puramente existencial pela comunicação. No que diz respeito a este último termo, com Jaspers, Martin Buber, Löwith; das Individuum in der Rolle des Mitmenschen (O indivíduo no papel do próximo), Griesebach e outros, nós o compreendemos como o ser puramente humano com o outro e para o outro e não “complicado” ou "perturbado” por algum dever ou algum serviço como é o caso para a autêntica relação de amizade, amor, autoridade ou a autêntica relação de confiança. A possibilidade da psicoterapia não repousa, portanto, sobre um segredo ou mistério, como se poderia entender, em suma, sobre nada de novo ou incomum, mas, ao contrário, sobre um traço fundamental da estrutura do ser-homem 
(Menschsein) como ser-no-mundo (In-der-welt-sein) (Heidegger) o ser com e para o outro. É à medida que este traço fundamental permanece "retido" na estrutura do ser-homem que a psicoterapia é possível. Se você se questiona sobre estas "possibilidades de ação" no interior desta esfera do ser-no-mundo, não é porque elas seriam, para você, aquilo que está o mais distante ou que é mais inabitual, mas sim porque elas são, para você, existenciais, ou seja, elas são, para você, o traço fundamental de sua presença ou existência, aquilo que está mais próximo ou é familiar; pois aquilo que está, para nós, existencialmente mais próximo, ou seja, nós mesmos e nossa relação com nossos próximos, aparece-nos teoricamente sempre em último lugar apenas; visão teórica e interrogação teórica requerem distância, espaço, um olhar firme, "tranqüilo" que se eleva sobre nosso ser cotidiano "distraído" e "agitado".

Se nos voltarmos, agora, para a segunda significação de nossa questão, a saber, de que maneira a psicoterapia pode realmente agir, ou de que maneira o psicoterapeuta médico obtém sucesso na ação psicoterapêutica em um determinado caso, devemos nos ater inicialmente a isto: o ser-médico impõe limites ao ser-com-o-próximo e em que medida ele o faz e acrescenta algo novo e em que medida ele o faz. Este elemento novo, isto o leitor já sabe, não pode nascer a partir do ser-com-um-outro-ele-mesmo, mas somente a partir do serviço médico relativo ao dever médico "prático", ou seja, a partir do saber médico-psicológico e da ação segundo o saber. Estas duas esferas - o ser-com-o-próximo e este elemento novo, o ser-médico - não estão em uma relação de um após o outro, do ao-lado-do-outro, ou a-partir-do-outro, mas em relação “dialética” um para-o-outro. A dialética que se estabelece entre o próprio solo materno (a pátria) de qualquer psicoterapia, a abertura factual (faktisch) biográfica do ser-com-e-para-o-outro, por um lado, e entre o conhecimento e o controle da "psique" considerada "organismo" de diferentes funções vitais biológico-psicológicas, por outro, esta dialética domina, com efeito, qualquer psicoterapia médica prática e todas as afirmações científicas a seu respeito. Comunicação na existência e ação dirigida para um objetivo de libertação e conduta de "forças" biológico-psicológicas, eis os dois pólos dialéticos da psicoterapia médica, na qual nenhum destes dois pólos pode aparecer só e único, assim como não pode apagar-se completamente em favor do outro. Isto quer dizer que, como psicoterapeuta médico, jamais poderia ser somente o "amigo" ou o apaixonado do doente como é o caso na relação puramente existencial, da mesma forma que jamais poderei me limitar ao serviço único do objeto. Um bom psicoterapeuta pode somente ser aquele que, para nos servir de uma excelente expressão de Martin Buber, pode ver com justeza em qualquer relação dialética o contraponto dominante e o utilizar conforme as regras da arte.

Um exemplo do dia a dia vai nos ajudar a esclarecer tudo o que precede e preparar o que vem a seguir: "Vamos evocar o caso de uma jovem, tratada no iní- 
cio, por nós, psicanaliticamente e em quem apareceu um estado de que sofre há dois anos. Durante a menstruação, ao longo de horas ou dias, ela emite, em espaços breves, ruídos fortes de soluços, ao passo que toda a musculatura respiratória, em particular o diafragma, mas também os músculos da cabeça e o território da musculatura enervada pelo facial direito, desde o músculo do pescoço até o orbicular, são atingidos por sacudidelas rítmicas. A sensibilidade é perfeitamente conservada, mas, durante este estado, o sentimento do corpo vivido falha, o que é um sintoma muito importante que sempre indica perturbações severas do sentimento de corpo vivido (Leib) ou da consciência do corpo vivido. A doente considera seu estado com uma discreta expressão de mártir sobre o rosto, mas no fundo com a belle indifférence que muitas histéricas mostram. Outros médicos haviam tentado diversos tratamentos para lutar contra este estado: hipnose, ergoterapia, efeito surpresa e de terror, faradismo... em vão; de forma que se resolveu, para aliviar a doente e acalmar o dissabor do meio, perturbado às vezes durante noites inteiras pelos ruídos dos soluços, utilizar o éter e o clorofórmio para obter uma leve narcose (a crise surpreende a doente ainda agora, durante a menstruação, mas dores leves na nuca são seus únicos pródromos). Apesar da boa relação que mantínhamos com nossa doente, não tivemos influência alguma sobre o quadro clínico, de modo que, uma hora após nossa visita, foi dada a autorização para tomar a dose habitual na garrafa de clorofórmio já preparada para este fim. A mesma crise reproduziu-se ainda uma vez naquele dia e no dia seguinte, com uma duração de uma hora e meia, e mais uma outra vez após um intervalo de dois dias. A doente estava há pouco em nosso estabelecimento em tratamento, as motivações mórbidas na anamnese da doente não puderam ser estabelecidas nem compreendidas seja pelo médico seja pela própria paciente. O leitor compreenderá que, para o médico, a situação apresentava-se de um modo difícil, espinhoso. Quando se trata de uma doença, ou seja, de neurose, ou a “doente” mantém a possibilidade de limitar o médico ao papel de observador passivo ou simples narcotizador, como sempre neste caso, ou será que o médico deveria "agir”, ou seja, aparecer como próximo e como médico e também estar em condições de assumir realmente este papel? Se ocorrer de ele ficar em desvantagem uma ou duas vezes, isto pode influenciar decisivamente todo o curso do tratamento, como no sentido negativo da psicanálise; por outro lado, se ousar uma intervenção psicoterapêutica e fracassar, é então que se coloca em jogo a saída favorável de todo o tratamento, e é esta uma das razões por que Freud sempre aconselhou não intervir ativamente durante o tratamento. Depositávamos pouca confiança na hipnose, em decorrência de seus resultados mínimos até o presente momento, exceção feita às nossas principais prevenções neste campo; por outro lado, como o leitor acaba de ver, não se podia esperar até o esclarecimento histórico da história da vida e do sofrimento, mas apesar desta advertência de não agir ativamente, era necessário mostrar que as exigências da situa- 
ção psicoterapêutica poderiam ser mais fortes que as advertências teóricas do Mestre. O que é decisivo em casos semelhantes é sua própria audácia e confiança na vitória, e não a teoria. Sempre nos lembraremos com que premência impôs-se a nós a idéia, ou, se preferir, a inspiração de nos aproximarmos docemente do leito da doente, colocar sobre seu pescoço os dedos de nossa mão direita e comprimir tão fortemente a traquéia que ela perdeu a respiração e se debateu para tentar libertar-se do estrangulamento e, quando a pressão relaxou por um momento, inspirar de novo com força. Foi assim que o soluço foi brutalmente interrompido para desaparecer completamente após duas ou três recaídas, que foram tratadas da mesma forma.

O leitor terá visto aqui um destes exemplos inumeráveis e variados, da forma como a psicoterapia pode realmente agir. O que aconteceu então? Nada de extraordinário, com certeza. Primeiramente, "algo se passou pela cabeça” do médico. É a primeira condição de toda arte psicoterapêutica, assim como de toda arte médica, podemos até dizer de toda a arte. Você deve sempre ter presente no espírito que a idéia é justamente uma idéia de artista e não de diletante, se ela brotar de uma lei estilística artística científica que dá sua dimensão à personalidade do médico em questão e que, por assim dizer, encarna-se nele. Isto vale para a idéia que germina no domínio da arte médica, assim como para a idéia que vai no sentido de um motivo musical ou poético. Tais idéias não caem do céu, a menos que sejamos gênios, da mesma maneira que tudo o que não é excepcional provém de uma trabalho obstinado e paciente, e sempre de um confronto entre o homem e as leis e regras objetivas de sua arte e ciência. A própria idéia consistia, portanto, naquilo que (de encontro ao distúrbio ou reviravolta tão poderosa e profundamente enraizada de uma forma de função biológico-fisiológica e da mesma forma manifestamente psicológica - um "ciclo de estrutura”, como diz von Weizsäcker) se chama de - e que se coloca em jogo - uma outra potência que esteja a altura desta outra potência vital "perturbadora” ou, se preferir, “demoníaca”, ou seja, a potência do sufocamento. Com bastante freqüência também, o médico psiquiatra, assim como o somatista, devem limitar-se em opor uma potência vital a uma outra, como o faria aquele que manipula os barbantes nos bastidores, na peça que a vida coloca em cena, seja adormecida na calma, seja revelando-se no ruído e furor. No presente caso, o leitor tem primeiramente um exemplo desta ação de bastidores cujo efeito expressa-se, do ponto de vista fisiológico, na interrupção do antiperistaltismo do soluço pelo estabelecimento de fortes deglutições próprias ao peristaltismo normal e, do ponto de vista psicológico funcional, pela recuperação do controle da inervação dos grandes grupos musculares cuja importância é vital e, pelo qual, a vontade da doente havia sido abandonada.

Não nos demoraremos mais sobre a ação da psicoterapia sobre o organismo e a psique no sentido de um conjunto unitário de funções vitais fisiopsicológicas, 
ou seja, sobre um dos pólos do ato psicoterapêutico. O outro pólo, a relação existencial entre o médico e o doente, também fala em nosso exemplo, mas uma intervenção psicoterapêutica como foi descrita somente pode agir - e não se deve arriscar - quando você se encontrar em uma relação existencial de comunicação e confiança expressa ou, melhor ainda, tácita, relação na qual o doente lhe "manifesta” confiança e em que você, médico, se sente "levado" pela confiança do doente em seu ser e ação, “levado” como o diz tão apropriadamente a língua alemã .

Esta confiança é o presente que o doente oferece ao médico como condição sine qua non de todo ato psicoterapêutico, e que se obtém menos, quanto mais se pedir, pois ela é como o presente de qualquer comunicação autêntica que supera a intenção, do meio e da meta, que supera a causa e o efeito. Se, em nosso caso, esta relação existencial não fosse prévia, nossa intervenção, ou seja, a tomada e a compressão da garganta, não teria tido efeito algum, ou, provavelmente, tivesse o efeito contrário, a saber, a amplificação do soluço e do cortejo de suas manifestações, a redução da doente a suas forças de defesa motoras, o despertar ou a intensificação da recusa psíquica do médico e mesmo, por exemplo, a manifestação de pura e simples antipatia, que pode ir até uma declaração de recusa de qualquer tratamento posterior etc. O leitor verá, então, que esta inspiração psicoterapêutica não poderia vir e não poderia ser conduzida satisfatoriamente, exceção feita à lei estilística geral, à arte médica ou à ciência, senão quando esta intuição correspondesse à "lei” individual do ser-em-comum concreto deste médico com esta paciente neste momento. É somente quando esta condição prévia é, também ela, preenchida, que a psicoterapia pode agir em conformidade com o sentido profundo da palavra "curar”. E isso não é tudo: o médico deve poder responder à confiança do doente, trazer-lhe de seu lado o presente de uma confiança humana se ele quiser que tal intervenção lhe seja sugerida e exitosa; o doente deve saber que o médico, sempre e em qualquer perspectiva, "está animado de boas intenções a seu respeito”, que ele quer ajudar com seu saber e talento, não como um objeto que se conserta, mas trazendo-lhe uma atenção confiante, como "pessoa”. Caso contrário, tal intervenção não chega à forma complexa de um ato psicoterapêutico, permanecendo o que é, uma simples ação, fora da esfera médica e humana: uma ameaça, e mesmo uma violência sobre o outro considerado um objeto, portanto, um ato de brutalidade. O psicoterapeuta deve evitar semelhante ato não apenas pelos motivos evocados acima, pois dá à doente uma razão para afastar-se dele, mas, pelo contrário - e o que pesa mais, no sentido estritamente psicológico, na balança - porque assim se desencadeiam na doente todos os instintos masoquistas da submissão, ou seja, o desejo de ser violada, desejo com o qual o sintoma justamente

3. Getragen, tomado no mesmo sentido metafórico que levado em português (no original em francês, a palavra utilizada foi porté). (N. da T.) 
não desaparece, mas, pelo contrário, é inicialmente fixado e ligado à pessoa do médico: esta intervenção tornar-se-á, então, uma fonte sempre renovável de satisfação masoquista à qual o doente aspira, tornando-se, assim, a ocasião de reaparecimento sempre renovado do sintoma. Já que raramente somos de essência apenas determinada pelo espírito, mas, com maior freqüência, também determinada por eros - uma oposição que, aliás, não é exclusiva, mas polar -, não se pode, nem se deve negar que, em nosso caso, tanto no médico quanto na doente, excitações instintivas tenham sido postas em jogo - violência no médico e submissão na doente; mas é justamente aqui que tal constatação em si e para si só significa pouca coisa, pois o que importa não é saber se incitações eróticas estavam ou não presentes, mas sim o que elas significam na totalidade do sentido do ato psicoterapêutico, ou seja, se elas escravizam o todo ou se a ele servem.

Por outro lado, é evidente que tal gesto psicoterapêutico deve ainda servir à análise biográfica e ser explicado por esta, pois, em si e para si, subsiste sempre uma dúvida: a relação de comunicação com o médico seria decisiva como tal, ou o médico não seria considerado, além disso, portador da imagem paterna ou materna? É por isso que é tão importante esclarecer este ponto, porque os doentes não devem simplesmente mudar seu submetimento biográfico ao pai, talvez, pelo submetimento ao médico. Voltaremos ainda a este duplo papel do médico, tomado apenas como "novo semelhante" e como portador de uma "velha” imagem, pertencente ao mundo de outrem.

No caso estudado aqui, a crise de soluço reapareceu durante a menstruação seguinte, mas pôde ser debelada da mesma maneira por um outro médico: o ato psicoterapêutico original já se tornara um rito. Nas menstruações seguintes, para grande decepção da doente, a crise ainda reapareceu, e, desta vez, acompanhada por violentas dores na bacia; mais uma vez ainda, a última, ela foi controlada da maneira ritual.

Neste ínterim, a biografia exterior e a história de vida íntima desta doente de vinte e seis anos puderam ser aprofundadas, ou seja, seu destino exterior, sua constituição, seu mundo comunitário e seu mundo ambiente, assim como as decisões de sua vida íntima: nossa doente é tão visivelmente fechada quanto de bem com a vida, tão apaixonada quanto intelectual, muito orgulhosa, "não suportando ninguém acima dela"; aos cinco anos, foi vítima de um grave tremor de terra que, naquele momento, não parecia ter provocado perturbações, mas que, segundo suas palavras, havia deixado atrás de si uma espécie de íncubo, de pesadelo, um traço ou uma marca que era revivida sob a forma de uma angústia profunda desde o menor tremor telúrico. Aos dezoito anos, no colégio, por ocasião de um medo de tremores de terra, medo muito forte, mas infundado, ela perdeu a voz pela primeira vez, após ter manifestado algum tempo antes tremores e vibrações bizarras em sua faringe. A cura foi obtida ao cabo de alguns meses pela aplicação que sua mãe fazia 
de cataplasmas muito quentes sobre o peito depois que todos os outros tratamentos, principalmente o faradismo sobre o pescoço durante quarenta dias, fracassaram. Foi aos vinte e quatro anos, portanto dois anos antes do início do tratamento atual, que, pela primeira vez, durante a menstruação, a crise de soluço surgiu acompanhada de violentas cefaléias posteriores, perda de apetite, náuseas e fortes contrações estomacais. Mesmo quadro durante a menstruação seguinte, mas desta vez acompanhado pela falta de voz ou afonia, de natureza indubitavelmente histérica, sobrevindo, portanto, pela segunda vez. Foi por causa da afonia e não pelo soluço que a doente solicitou tratamento em nosso estabelecimento. A análise informounos que o quadro clínico atual não foi provocado por uma experiência vivida aterrorizante - um pretenso tremor de terra - como fora o caso na primeira vez, mas por uma decisão própria ligada à biografia, ou seja, por um sentimento de desgosto pela vida e de oposição à sua mãe, no fundo ternamente amada, mas enérgica e rígida, que recusara a permissão para o noivado com o jovem que ela amava.

Com a descoberta da motivação responsável pelo aparecimento e permanência da afonia, graças ao conteúdo vivido de revolta contra a proibição da mãe, e mesmo de punição, a afonia desapareceu alguns meses depois, sendo a doente sustentada por uma ação de pretensa psicoterapia social, ou seja, por uma intervenção em suas relações sociais, aqui, relações com a família. Após a elucidação da gênese do sintoma, os pais foram convencidos a autorizar o noivado da filha com o jovem de sua escolha, contra o qual, aliás, parecia não haver queixa válida alguma. Pouco depois, no entanto, este jovem revelou-se um verdadeiro crápula, o noivado foi rompido, mas nem o soluço, nem a afonia reapareceram. Mais madura e sensata por causa da análise, a jovem não considerou a invasão do destino em sua vida como sendo tão "pessoal” quanto em relação à sua mãe, contrariamente aos nossos doentes neuróticos que, na presença de frustrações do destino, conduzem-se como a criança ante a recusa de sua governanta em atender um de seus desejos. Cinco anos passaram-se, nossa jovem paciente permaneceu celibatária. Isto é tudo o que podemos dizer e, na falta de informações, não sabemos se é preciso ter como responsáveis as relações externas ou as ligações biográficas persistentes.

Pincelamos, superficialmente, o processo de tratamento psicoterapêutico de nossa doente, não que ele indicasse algo em particular, em si e para si, mas porque o leitor pode daí deduzir como a psicoterapia "pode agir" como estratégia, ou seja, algo global a partir de decisões e métodos particulares, táticos e psicoterapêuticos; em nosso caso, por exemplo, a psicoterapia agiu como um todo a partir de um ato psicoterapêutico isolado, um rito psicoterapêutico que daí adveio, uma intervenção socialmente psicoterapêutica e um certo método psicoterapêutico, fundamental no sentido da exploração sistemática da biografia exterior e da história interior da vida. Não é necessário aprofundarmo-nos mais no efeito da "força" por meio da qual esta intervenção social - ou seja, o desejo de autorização de se casar com um ho- 
mem amado - podia agir terapeuticamente, ação que, certamente, nada tem de extraordinária. É preciso apenas ter em mente que esta intervenção social não teria sido tão claramente reconhecida em sua significação terapêutica sem uma penetração mais precisa da história interior da vida, não teria sido conduzida para um objetivo preciso e não teria tão rapidamente se resolvido; sem dúvida, esta intervenção social sustentou efetivamente, de seu lado, o sucesso terapêutico da análise.

Agora, no que se refere ao fator psicoterapêutico de cura mais importante, ou seja, a exploração metódica da história interior da vida, o leitor encontrará, aqui, em um desenvolvimento histórico que cobre um importante lapso de tempo, tudo o que dissemos em acréscimo ao ato psicoterapêutico particular. Em vez da inspiração vinda da situação médica global e da comunicação puramente pessoal e em vez de sua transposição instantânea em uma intervenção que funda uma forma funcional "normal”, uma situação médica nova e uma nova comunicação, entra, aqui, em jogo, o trabalho paciente, comum, sistemático, para uma reconstituição das experiências vividas e uma reconstrução refletida da história interior da vida, trabalho absolutamente criativo para os dois parceiros, trabalho feito pela reunião dos atos de experiências, compreensão e interpretação que, um primeiro momento, formando em uns com os outros um tecido frouxo, aparecem pouco a pouco como cada vez mais forte e sistematicamente ligados e estruturados, de modo que, em vez da intervenção intuitiva, o tema, nesta hora, torna-se determinante. Toda a história interior da vida de um ser, pouco importa que ela se desenrole de modo lógico e direto, caprichoso e tortuoso, não representa nada além de um tema histórico, tema que, inesgotável em si, "reúne-se" a partir de temas principais diversos e sempre inesgotáveis que, eles próprios, se edificam a partir de diversos subtemas. Quanto mais o trabalho psicoterapêutico progride, mais a relação temática torna-se um guia e mais se esfumaça o arbitrário da inspiração. Esta cura psicoterapêutica não representa apenas um trabalho espiritual em comum aplicado a um objeto ou a um problema comum, um serviço ou uma performance conseqüentemente, mas também um contato comunicativo e uma influência recíproca ininterruptos, o que é o elemento decisivo próprio a qualquer tratamento psíquico. De forma alguma, esta comunicação deve ser, como crêem os psicanalistas ortodoxos, apreendida como simples repetição, portanto, no caso positivo, como transferência e contratransferência e, no negativo, como resistência e contra-resistência, pois a relação entre doente e médico representa um fato novo e autônomo de comunicação, um laço novo criado pelos dois destinos não somente em função da relação doente-médico, mas ainda, e principalmente, em função da relação puramente humana, no sentido de uma autêntica colaboração. Se tal tratamento fracassa, o analista está, então, inclinado a admitir que o paciente é incapaz de superar suas resistências contra o médico, considerado, por exemplo, como "imagem paterna". O elemento decisivo do problema de se uma análise pode ou não agir psicoterapeuticamente com fre- 
qüência não repousa sobre o fato de saber se um doente pode superar as resistências contra a imagem paterna transferida sobre o médico e assim ficar livre e responsável por si, mas sim sobre o fato de saber se ele pode ou não vencer suas resistências contra o pai com o auxílio deste médico; em outras palavras, se não é a recusa deste médico como ser humano, ou seja, a impossibilidade de entrar com ele em relação autêntica que impeça a interrupção da “eterna” repetição da resistência contra o pai. A teoria psicanalítica, sabe-se, intimidade em relação ao mecanismo e, portanto, em relação à repetição (mecânica), fica curiosamente cega a propósito da categoria do fato novo, e, conseqüentemente, a propósito do elemento propriamente criativo na vida da alma. ${ }^{4}$ Imputar a culpa do fracasso apenas ao doente nem sempre corresponde aos fatos; nós, médicos, deveríamos sim nos perguntar se o erro não repousa às vezes sobre nós. Não queremos naturalmente fazer alusão, aqui, a um erro no plano técnico, mas a um erro bem mais profundo, a incapacidade de despertar ou atiçar no doente "a chama divina” que não pode ser despertada ou atiçada senão em uma comunicação autêntica de existência para existência e cuja clareza e calor são os únicos, no fundo, capazes de libertar o ser do isolamento cego do idios cosmos, como diz Heráclito, ou seja, da simples vida em seu corpo, de seus sonhos, de suas inclinações privadas, de seu orgulho e de sua exuberância e elevá-lo e liberá-lo para que possa participar do koinos cosmos, da vida da koinonia autêntica ou da comunidade.

A exploração da história interior da vida foi fácil em nosso caso, já que bastou, em suma, para dar acesso à cura, reconstituir, em conformidade com a experiência vivida, o tema do conflito atual com a mãe e o tema do conflito que daí decorria diretamente entre a vontade de morte e de vida, ou de amor, e lhe mostrar o lugar que é conveniente designar-lhe em sua própria vida. Também aqui, no entanto, aconteceram importantes peripécias nas relações de comunicação entre a confiança e a afeição depositadas pela doente no médico e o trabalho em comum positivo, por um lado, e entre a decepção, a recusa de alívio e o trabalho em comum, por outro. Enfim, o médico consegue tirar implicações da "identificação" com a mãe e o pai e voltar a uma relação de comunicação direta com sua doente.

A questão que persiste, sem dúvida, no espírito do leitor e que eu ainda não respondi é, certamente, esta: ao admitir que a análise histórica seja exata, ao admitir também que, graças à técnica analítica, à intervenção social psicoterapêutica e ao esclarecimento da comunicação, a doente tenha podido decidir voltar em sua decisão anterior e, por uma determinação nova, renunciar à sua revolta contra a

4. Com relação à crítica da psicanálise neste escrito, o leitor atento não deixa de ver quanto o autor deve à psicanálise e quanto as idéias expostas aqui contêm justamente o germe de uma elaboração posterior das teorias psicanalíticas. 
“vida”, em geral, e contra a mãe, em particular, como seria possível compreender que ela tenha recuperado o controle de sua voz que lhe havia sido completamente retirado durante dois anos? Talvez o leitor compreenda como foi possível, por um trabalho em comum, levar a doente a querer novamente falar em voz alta, mas ele não compreende como este querer pode se converter em um poder; pois, de qualquer forma, deve-se absolutamente excluir aqui uma possibilidade de simulação, o que a pergunta talvez pudesse insinuar. Nesta relação doente-médico, é muito importante dar atenção ao que estes doentes observam de si mesmos durante sua convalescença, em relação à recuperação do controle de seu corpo vivido e ao desaparecimento do sintoma. Eles explicam freqüentemente que têm a impressão de ter esquecido algo, por exemplo um nome, e que pareceu que a coisa esquecida queria voltar à consciência a todo momento, mas ela desaparecia novamente até que um dia surgiu bruscamente no espírito, clara, precisa e à disposição. O mesmo aconteceu com nossa doente com a reconquista de sua voz e a recuperação do controle sobre esta.

Se o leitor quiser, agora, compreender o que, propriamente dito, se passa, ele não deverá pensar em alguma das teorias psicofísicas, em algum paralelismo ou em uma interação psicofísica inútil para nós em psicologia e em psicopatologia. Pedir-lhe-emos para apenas pensar como "o corpo vivido" torna-se de novo psicológica e psicopatologicamente importante, principalmente como dado ou consciência corporal, com todo o a priori de suas leis essenciais e as possibilidades de alteração de sua "facticidade". Em primeiro lugar, o leitor irá se perguntar como o doente vive em seu corpo vivido, ou melhor, como ele experimenta seu corpo vivido e como ele o "sente". Por este modo de sentir, não deverá compreender nem sensações sensoriais nem sensações de órgãos, nem sensações corporais vividas particulares, e principalmente não percepções corporais ópticas ou táteis ("externas"), mas um estado de fato fenomenal, absolutamente unitário e singular, de ter um corpo vivido e experimentá-lo, estado de fato que, como Scheler tão claramente mostrou e Plesner tão minuciosamente estudou, é dado a toda sensação isolada, factual do corpo vivido como "categoria”, como forma essencial "pura" ou como norma. Já Schelling reconheceu a singularidade fenomenal desta esfera das essências, afastando-a da esfera espírito-objeto, e particularizando-a como esfera alma-corpo (Seele-Leibsphäre) explicando: “O espírito tem apenas uma relação com o corpo (Körper), a alma com o corpo vivido (Leib); o corpo vivido é sentido, o corpo é apreendido.” Mas já nas teorias da cura nos hindus e em Plotin, esta esfera da "corporeidade", o "ter-um-corpo-vivido" e a manifestação em si, como forma existencial singular, fora reconhecida em sua particularidade fenomenal da forma mais radical e em oposição a outras formas de existência. Para nossa época, citaremos apenas os trabalhos de Klages, Erwin Straus, Buytendijk, Heinz Werner e, especificamente, os de von Weizsäcker, trabalhos que nos permitiram enrique- 
cer e aprofundar nosso conhecimento da esfera corporal, no que ela tem de fatual e empírico. Nós nos separamos de von Weizsäcker principalmente quando ele objetiva a esfera da "corporeidade” e a apreende como "acontecimento" do corpo vivido (ver "Acontecimentos corporais e neurose"), ao passo que estamos persuadidos de que, aqui, devemos nos manter tão longe quanto possível de uma apreensão objetivante e permanecer na esfera do vivido corporal. A objetivação leva imediatamente à teoria e à tentativa de "transposição" da oposição entre físico e psíquico, enquanto nós mesmos queremos cavar um "túnel” sob esta oposição, o que não é possível senão à medida que ficamos no plano puramente fenomenal, ou seja, no interior da esfera da experiência vivida e da significação ou, em outras palavras, na esfera da existência. É nestas teorias que você, leitor, deve pensar e não naquela que a fisiologia ensinou (que faz da corporeidade um conjunto funcional puramente biológico-objetivo), se quiser compreender como nossa doente reencontrou sua voz e como neste caso a psicoterapia "agiu”, e mesmo o que está estreitamente ligado à possibilidade desta compreensão, como ela perdeu sua voz.

Enquanto nos pacientes ignorantes, parece que tal sintoma explode brutalmente em pleno céu azul, como reativo a um acontecimento dado, nos doentes cultivados, habituados à introspecção, pode-se reconhecer uma incubação de uma maior ou menor duração com estágios intermediários variados. Em nossa doente, como você sabe, a dolorosa crise de soluço apareceu antes da afonia, enquanto as manifestações prodrômicas tinham, elas próprias, no entanto, precedido esta. O ponto de partida de todo este conjunto fora a proibição da mãe de ela participar de um determinado baile em que esperava encontrar seu bem-amado. Além disso, introduziram-se primeiramente a perda do apetite e do sono, de que já falamos, vagas tendências ao suicídio manifestaram-se e apareceu o sentimento de estar seriamente doente organicamente e o desejo de ver ainda uma vez o bem-amado em seu leito de agonia. Todas estas coisas são bastante cotidianas e conhecidas e o leitor irá se perguntar por que nos atemos a isso. Mas avancemos. Após três semanas em que a doente, fisicamente, continuava ainda mais “abatida”, a menstruação apareceu, ou seja, uma outra modificação da experiência corporal, em si e para si, particularmente importante. Sobrevieram, então, como já mencionados, as náuseas, depois os vômitos e as cefaléias violentas, aos quais acrescentaram-se, desde o terceiro dia, cólicas estomacais muito dolorosas, com acidez e arrotos que duraram dias e que se transformaram progressivamente em crise de soluço. Como já dissemos, não é necessário considerar estas perturbações do ponto de vista do fisiologista ou do fisiopatologista, porque não compreenderíamos nada; pois se deve não apenas saber que o homem possui um corpo vivido e como este corpo vivido é feito, mas também que, ele próprio, é permanentemente de um ou de outro jeito um corpo vivido. Isto, no entanto, não significa que ele viva sempre corporalmente, tanto de um quanto de outro, mas, pelo contrário, que ele fala ou se expressa 
sem cessar corporalmente de uma maneira ou de outra, que ele possui, portanto, ao lado da palavra articulada em voz alta ou ao lado de uma linguagem figurada mais ou menos objetiva, uma linguagem do corpo muito claramente articulada. $\mathrm{O}$ ser humano expressa-se sempre nesta linguagem, de um modo particularmente inteligível quando, na seqüência do abandono da comunicação e do fechamento em si mesmo, não mais se trata de meio de expressão próprio da comunicação, nem da linguagem falada, quando também a imaginação criadora cala-se e o homem fecha-se no silêncio de sua tormenta. Mas o ser humano é a tal ponto uma essência falante, no sentido mais extenso, que ele expressa ainda algo: Bleuler sempre insistiu que a doente - que não deve ser considerada uma "histérica", no sentido corrente do termo, ou seja, um ser de caráter fraco em que não se pode confiar, principalmente inclinado a formas de expressão não autênticas e espetaculares, por tudo o que, no fundo, nada deve ter a ver com a histeria no sentido puramente clínico sofre verdadeiramente. A proibição da mãe e a obrigação de renunciar a seu amor desferiram um golpe muito duro em sua vontade de viver; ela se retira da vida, mas não pode nem quer seriamente morrer. Assim, ela vive constantemente entre a vida e a morte, sem objetivo nem desígnio, é este o terreno mais fértil para a eclosão de uma neurose, se não quisermos designar, em si e para si, o que é mais exato, esta forma de vida ou de existência da meia-medida e da indecisão como ambivalência neurótica, em suma, como neurose. É nesta forma de ser que a esfera da corporeidade assume significação nova, ela que, de outro modo, representa seja um horizonte (Horizon) mudo e um pano de fundo indeciso, um ponto de apoio mediano ou um primeiro plano mais ou menos nítido ou, ainda, uma esfera de atividade bem estruturada de nosso ser. Depois de todo o resto, o mundo comum assim como o mundo ambiente, ter sido "sufocado", perder o sentido, o objetivo, isto é, ficar sem vida, a corporeidade tornou-se uma retirada, a retirada de nosso ser, uma retirada que, de alguma forma, não dá uma impressão de tranqüilidade e intimidade, mas que se apresenta de um modo angustiante como o "sítio" da simples pressão vital, agora inquietante, cega e sem objetivo, que nos atormenta, nos aterroriza e nos angustia; pois para onde a simples pressão vital nos impele, nos encurrala, encontramos a beira do abismo, do vazio existencial total, do nada ${ }^{5}$ (um sofrimento que nos faz compreender que tanto seres tentem combatê-lo pelas drogas, não mais suportando a vida senão na embriaguez ou narcose e tornam-se alcoólicos ou morfinômanos). O corpo vivido continua a "funcionar" aqui "sozinho” e, isto, de uma maneira rebelde, porque não regida nem guiada por um sentido

5. O exemplo conhecido por todos, considerado "normal”, tirado da vida cotidiana para descrever este vazio existencial e o vivido corporal opressor ou perturbador que daí vem é o “tédio” e o movimento "monótono" da experiência vivida que lhe corresponde. 
próprio e, nesta revolta, ele também se encarrega da função da linguagem, tornase no sentido mais amplo do termo o órgão verbal desta revolta. Mas é também pela retirada em meu corpo, em “mim como corpo vivido", que eu falo. É uma coisa bem conhecida pelas linguagens populares, onde se encontram escondidos grandes tesouros desconhecidos sob este ponto de vista. E não apenas dirigimos este saber para nossa paciente quando, na incapacidade de absorver e conservar a obrigação e rejeitá-la em que a revolta a coloca, vemos a expressão concreta da linguagem corporal, de sua incapacidade em geral, de “engolir” e digerir algo que ameaça seu instinto de vida, algo que não lhe convém, tudo o que existencialmente não é assimilável por ela; e aplicamos ainda este saber quando vemos este algo inassimilável na proibição da mãe de participar do baile e de noivar com seu bem-amado e ainda quando explicamos sem rodeios: a doente não pode engolir a proibição da mãe, ela não pode nem engolir nem digerir o golpe e a ofensa dirigidos contra seu amor e vontade de viver. De onde a sabedoria da linguagem popular extrairia tal expressão, se não a criasse a partir da vida cotidiana e do saber do povo? É uma destas expressões populares e não na hipocrisia dos termos técnicos eruditos que vemos, melhor expressa, a autêntica unidade da alma e do corpo vivido, o autêntico ser-homem.

O leitor não deve, no entanto, crer que se trata em nosso exemplo, como freqüentemente é o caso, de uma analogia ou de uma simples metáfora à medida que algo de psíquico seria descrito de forma analógica ou metafórica por meio de uma expressão corporal (leiblich); pois aqui não se trata, como já mostramos a propósito da ascensão e da queda, de uma questão de denominação no sentido de uma simples escolha de expressão, mas, pelo contrário, trata-se de algo que repousa bem mais profundamente, a saber, do fato de que nossa existência sempre se abre em determinadas direções significativas (Bedeutungsrichtungen), ou seja, a ascensão ou a queda, o adejamento ou o salto, o tornar-se largo ou estreito, cheio ou vazio, claro ou obscuro, terno ou duro, quente ou frio etc. Em nosso caso, no entanto, tratava-se de tomar, aceitar, absorver, em suma, da "assimilação" e do "refluxo" do sujeito, da resistência, em uma palavra, da "expectoração”. Estas direções significativas essencialmente unitárias, a própria linguagem dissocia-as em modos de expressão corporais, psíquicos, espirituais; entretanto, não poderia trocar estes modos de expressão uns com os outros, e principalmente não poderia trocá-los com tal leveza e uma tal certeza imediata do ser-compreendido, se elas não se fundassem sobre uma forma unitária vivida. Não devemos procurar o conhecimento desta unidade na ciência, mas sim onde ela está conservada e onde se manifesta, justamente na linguagem popular e suas caracterizações do homem, onde ela é consignada nos provérbios, palavrões, conceitos, injúrias, imagens e comparações. De forma alguma, comparamos a deglutição fisiológica, elemento já cientificamente isolado a partir de um todo na origem unitariamente antropológica 
e, portanto, fisiológica, com a abstração fisiológica da raiva, da vingança, da tristeza, do desespero, mas, em ambos, vemos apenas expressões particulares específicas para um único e mesmo estado de fato existencial. Quer chamemos revolta psíquica a raiva, uma incapacidade de engolir, ou que chamemos a incapacidade de engolir revolta psíquica ou raiva, no fundo, é a mesma coisa quando a linguagem popular dá preferência à evidência no primeiro caso. Nós vivemos de um modo muito mais unitário do que pensamos, e mesmo que "falamos", e um grande número de problemas de pensamento desfazem-se quando os transformamos em problema vital correspondente. Colocamo-nos, pois, face à teoria habitual da sensibilidade, recusando-a exatamente como a de James Lange; nada há aí de primário ou secundário, nem causa nem efeito, nem fundamento nem conseqüência. Não temos nem um sentimento de terror nem de decepção porque sofremos de uma perda de tônus, nem sofremos de uma perda de tônus porque temos medo; o medo e a perda de tônus são, antes, duas expressões verbais diferentes, corporalmente - psiquicamente diferenciadas, por um único e mesmo fato, a saber, a retirada e a vacilação da "orientação" de nossa existência em seu espaço global, histórico-biográfico vital e dimensional. Não se deve de forma alguma, como foi com freqüência feito levianamente, dar, com relação a isto, uma indicação apenas negativa, ou seja, "psicofisicamente neutra", mas é preciso distingui-la positivamente, ou seja, existencialmente; no último caso, trata-se de uma mudança da direção significativa a partir da significação da segurança existencial em direção à significação da comoção existencial "no espaço" etc., ou então, em nosso caso, como a transformação da direção significativa a partir da "assimilação" existencial, ou seja, a partir da significação tanto biográfica quanto vital e dimensional daquilo que é para mim e em mim, na significação daquilo que é rejeitado de mim e para fora de mim, ou seja, a expectoração existencial. A nosso ver, não se atinge todo o problema, portanto, quando se declara simplesmente que uma excitação psíquica de defesa "convertese em elemento corporal", mas deve-se compreender que o "corporal”, a corporeidade, é apenas uma forma particular da existência humana, que, em certas circunstâncias, permanece o único “campo de expressão” e por ser assim e porque o ser humano utiliza esta linguagem, é que em vez de se enraivecer e vaticinar, ele cacareja, arrota, grita e "vomita". Quando ele atinge um grau mais importante que a média, chamamos este fato antropológico reduzido à clínica: doença e, quando o limitamos ao estabelecimento de um diagnóstico standard: histeria.

Em nossa doente, a perda de apetite e sono, a náusea e as cólicas estomacais representam a primeira etapa da doença, o acesso de soluço, a segunda e, nas menstruações seguintes, aparece a terceira e última etapa: a afonia, ou, para expressar positivamente, o murmúrio que agora acompanha o cacarejo temporário como sintoma durável. É neste cochicho que devemos perceber uma nova renúncia à comunicação e, indiretamente, uma nova punição infligida à mãe. Trata-se de um 
novo fechamento para a vida em comunidade, o que sempre significa uma vida orientada para o distante e o futuro, para a vida no ser só (que não deve ser confundido com a solidão), uma vida no idios cosmos, na pura corporeidade e proximidade corporal sem futuro e que se conduz languidamente. Este fechamento encontra mais facilmente uma via quando uma via análoga fora existencialmente traçada pelo terror provocado pelo tremor de terra e que a segurança física vital já havia experimentado uma ameaça renovada no sentido de uma ameaça mortal. Tal ameaça remete-nos à nossa própria existência já que nós, cada um por si, devemos nos arranjar com os problemas de nossa morte e daquilo que ameaça nossa vida. Também aqui, é a linguagem popular que nos informa. Um "desmaia” de terror, para o outro é o terror que "penetra seus membros", o terceiro "fica mudo" de terror, para o quarto, o terror faz com que "suje as calças", o quinto torna-se "pálido como um morto”, no geral, portanto, vemos paralisia, inibição, "perda de tônus”, perda do controle total dos domínios diferentes da corporeidade, mais exatamente incapacidade de se abrir neste domínio da corporeidade. Por que, dentre todas estas possibilidades provenientes do terror provocado pelo tremor de terra, nossa doente efetuou justamente sua renúncia no domínio da voz e não alterou a marcha ou sua capacidade de manter-se de pé (abasia ou astasia)? Não pudemos esclarecer se, por exemplo, experiências vividas e pulsões instintivas ainda não diferenciadas e, principalmente, de ordem erótica etc. "agiram”.

Agora é fácil compreender, por outro lado, por que, a favor de uma nova experiência vivida existencial de preconceito e ameaça, a zona oral tornava-se região privilegiada para sofrer um novo ataque, zona que, excluindo-se qualquer interpretação puramente psicanalítica, representa com certeza, no entanto, em certa medida e na dimensão que lhe é atribuída, um ciclo de funcionamento unitário, psicofísico, e por que este novo ataque, no final das contas, utilizou de novo a expressão da experiência vivida anterior: a afonia. Será que não se trata justamente aqui, como em outro lugares, desta direção existencial da significação que se refere à entrada e à saída, às trocas internas e externas entre o mundo próprio, o mundo ambiente e o mundo comunitário e que teremos ainda mais direito de chamar pólo oral ou, se preferirmos, oralidade, quando reconhecemos melhor que aqui a sexualidade não desempenha um papel genético ou causal, mas representa simplesmente um caso singular, apesar de muito importante no plano vital, uma parte desta direção significativa existencial comum. Este fato explica justamente que as diferentes significações singulares e sua importância singular, como, por exemplo, as significações sexuais nutritivas e comunicativas no plano psíquico, podem se reunir, se representar, se favorecer e se inibir. Uma coisa é saber por experiência que historicamente, no início de uma biografia que chamamos neurótica, sempre há conteúdos sexuais vividos ou imaginados - nossas próprias experiências aqui reúnem-se às da psicanálise ortodoxa - e outra coisa é colocar como uma afirmação evolucio- 
nista que o "sexual" representaria a base genética para todas as outras formas de experiência, como tais, fundando-se sobre uma especulação teórica.

O leitor compreenderá melhor, assim, de que maneira a psicoterapia podia agir sobre a afonia. Ele verá que, propriamente falando, tratou-se de uma hierarquia das ações, ao contrário da maioria dos casos em que, como regra geral, a afonia é suprimida em uma única sessão por sugestão. Em tais casos, trata-se de casos recentes em que o sintoma somente apareceu após algumas horas ou dias (para depois reaparecer em cada ocasião), ou então de um ser humano menos "sério" e que deve ser levado menos a sério, ou de um sofrimento e de um conflito psicológico menos profundo. No que diz respeito à ação citada acima, a saber, o despertar do desejo da doente de deixar seu isolamento para voltar à vida da comunidade, já discutimos: não se tratava de um aumento de sua vontade de restabelecer a saúde, como deve ser com freqüência o caso nos seres brincalhões e menos sérios, mas absolutamente de um despertar e de um reforço de sua vontade de viver, provocando, então, sua decisão rumo à plena realidade da vida. A ação seguinte consiste em que a relação de motivação entre a decisão de "retirar-se" da vida e a comunicação viva (a própria doente falava de um desligamento da vida, e a perda do discurso em voz alta tornava-se não apenas compreensível, mas lhe era reconstituída, ou seja, plenamente revivida; a terceira ação consistiu em sua voz realmente voltar ou reintegrou sua memória, retorno que, quando não se trata de distúrbios orgânicos, significa ao mesmo tempo que algo pode estar sendo novamente reproduzido, inervado, aqui diremos que pode estar sendo entoado.

Em relação a esta última ação psicoterapêutica que, como regra geral, não está, com certeza, particularmente mencionada e representada, podemos apenas conduzir nossos doentes até a porta principal da cura; o passo necessário para transpô-la, devem dar sozinhos. Podemos, sim, ajudá-los a fazer recuar os recalcamentos, como diz Freud, e levá-los de modo que o recalcamento transforme-se em simples esquecimento, como é o caso, por exemplo, quando esquecemos o nome de uma pessoa indiferente, mas não podemos "fazer" com que aquilo que foi, por eles, esquecido, aqui a força cinestésica da "voz", seja, por eles, novamente "empunhado" (pois esta última importa muito mais do que a simples forma do som, apesar de que, aqui, naturalmente, a forma do som e a do movimento estejam muito próximas uma da outra).

Devemos, agora, uma vez mais, retroceder um pouco. O sintoma histérico não significa, como vimos, senão a expressão corporal especial, a articulação e a acentuação corporais de um modo de existir geral voltado sobre a corporeidade e a linguagem do corpo, um modo de existir extremamente imperfeito, ou seja, "deficiente”. Uma vez a existência encontre-se tomada em tal expressão corporal, ela perde, então, qualquer relação com o passado e com o futuro, o que significa simplesmente que o ser humano destituiu-se de seu próprio destino, implicando histó- 
ria e temporalidade e que ele está obrigado a levar uma vida sem passado nem futuro autênticos e mesmo, propriamente falando, sem presente autêntico, sem perenidade nem expectativa e também sem possibilidade de se instruir ou amadurecer, uma vida, portanto, puramente corporal (tudo isso está contido em uma única fórmula: "inconscientemente"). Ao longo do tratamento, da educação e da comunicação psicoterapêutica, este status quo existencial realoca-se na "corrente”; a memória do passado volta, o futuro é esperado, a vida na corporeidade é reconhecida como sendo o recôndito de toda vida própria, como um status quo "artificial” e a isto renunciamos, a expressão corporal é, neste sentido, compreendida e traduzida e, assim, finalmente, não há mais obstáculos à vida livre na esfera do corpo vivido, ao seu livre curso (ao contrário de sua "estagnação", de sua fixação em um "sintoma” físico, por um lado, na abolição total do sentimento do corpo vivido, por outro). Nossa doente tem agora somente um último esforço a fazer, comparável ao que fazemos quando procuramos um nome esquecido ou, para falar em termos de neurologia, sua forma de ressonância, de movimento e de imagem. O leitor observará que ele não procura estas formas "no cérebro", isto é coisa de neurologista (cuja pesquisa e descoberta estão orientadas em uma direção diferente, viva, que falamos aqui), mas sim na "cabeça”, no “ouvido”, no "olho”, na "língua”, na "garganta”, nos "lábios”, nos "dedos” etc. Isto significa que ele a procura em sua esfera corporal ou em sua corporeidade, sobre a qual já sabe que não constitui uma "parte" de si mesmo, mas que lhe é, de alguma forma, inerente. Ele próprio procura igualmente para si, em um nome esquecido, uma certa forma de perplexidade no interior de sua existência corporal que o impede de ficar satisfeito "consigo" quando não encontra o nome procurado (isto vale igualmente para as "imagens", portanto, acima de tudo, para as imagens oníricas; estas também são nós mesmos). E quando nossa doente nos diz que o controle de sua voz, como algo de que houvesse se esquecido, ora volta ora desaparece, vemos aí o último resto de seu próprio esquecimento, de sua perplexidade em escolher a si mesma e de seu "sertomado-pelo-corpo"; em outras palavras, de sua estagnação existencial, de sua supressão, de sua aderência, como cada um de nós o experimentou no "estado" do ser que reflete sobre algo esquecido e, não apenas neste estado, vivemos isto com bastante freqüência já que é somente em raros momentos que estamos "completamente conosco" ou que somos "completamente nós mesmos". No entanto, mesmo nestes momentos, mesmo nestes raros instantes de "estar inteiramente conosco", não nos retiramos completamente da esfera corporal, mas vivemos nela, então, de uma maneira totalmente diferente, pois, em lugar desta maneira que é justamente chamada ceptora e receptora na existência na língua, lábios e dedos, no olho e no ouvido, aparece, então, quando somos completamente nós mesmos, um tipo de existência puramente central. Para designar este modo de existência, talvez a linguagem popular tenha justamente a expressão mais preciosa de todo o tesouro da 
linguagem popular: o coração. São momentos em que "nosso coração fala”, o centro, a profundeza de nosso ser próprio, nos quais as palavras "vêm do coração", nos quais o cristão agostiniano percebe a palavra de Deus e a profere, este verbo que não mais vem da boca, mas, como diz santo Agostinho: ex corde sonat.

Voltemos, entretanto, à periferia, em busca de um nome esquecido. Também desse ponto de vista, santo Agostinho é, para nós, uma preciosa referência. Ele descreve esta busca (Confissões, cap. X, 19), à qual, a nosso ver, até hoje não demos a devida atenção, inspirando-se completamente nos princípios da forma e, acima de tudo, no princípio do todo, quando, no lugar de si, ele fala da memória, memoria, que, para ele, representa o próprio ser criador e espiritual. No esquecimento, a memória é manca (claudicans) e estropiada (obtruncata), onde a memória estava habituada, falta algo de uma ligação à qual estava habituada, a parte nela conservada procura apaixonadamente o elo esquecido que lhe falta até que, pela recusa de todas as outras partes não adequadas, agitada, repelida daqui e dali, entre os impulsos para adiante (a busca e a estagnação), tenhamos encontrado com um “eis!” de vitória, o elo que faltava. William James que, em seus Princípios (I, 251 e ss.), descreve exatamente o mesmo processo de busca de um nome esquecido, jamais superou, de forma alguma, santo Agostinho, exceção feita para as posições terminológicas relativas à intention anticipatory e os premonitory perspective views, aos quais atribui, com justeza, a parte preponderante de nossa vida psíquica. Todos estes hábitos (consuetudines) e suas “mutilações”, todas estas intentions por antecipação (anticipatory), todas estas referências subseqüentes a uma determinada perspectiva que investiga o futuro, não se referem absolutamente a formas de ser absolutamente espirituais ou somente psíquicas, mas implicam bem mais do que as expressões verbais têm, parcialmente, conservado com certas formas e atitudes da corporeidade, da vida da esfera corporal vivida e, principalmente, do "procedimento", da atitude, da “mão" e do "olho".

Fechemos o fato, que em todos os lugares aqui são considerados, na estreita gaiola da expressão consciente-inconsciente e obstruamos qualquer visão da possibilidade de compreendê-lo, a menos que talvez voltemos a Leibniz que tornou esta oposição familiar à psicologia alemã, mas a compreendeu de forma totalmente metafísica. Apesar de não mais partilharmos estas perspectivas metafísicas, estamos, no entanto, obrigados a constatar, aqui e no plano de sua relação, intensidade crescente da consciência com o aumento da clareza e precisão das representações, com o desenvolvimento da inteligência em relação às verdades eternas que permite o aprofundamento exitoso do conhecimento de si, e mesmo a maturação de "nosso eu mesmo". Leibniz está bem mais próximo de nós do que um Herbart, um Fechner ou do que a concepção topológico-quantitativa de Freud, apesar de Freud, por outro lado, ter justamente visto muito bem aquilo de que aqui se trata, se não na forma, pelo menos para o fundo. 
Freud não nos ensinou justamente a compreender o "não posso" dos doentes como um "não quero" e, conseqüentemente, a relação "eu/não-eu”, como a relação "eu/eu mesmo", e a psicanálise não tem verdadeiramente direito à existência senão à medida que esta tradução é possível ou, pelo menos, tem um sentido? Freud, no entanto, transforma uma vez mais em uma intenção "suicida", no sentido próprio do termo, o não quero em um isso não é possível. É sempre o mecanismo de causa, efeito, intensidade, linhas de força etc. que, com todo o seu acompanhamento conceitual, subentende a conscientização de um conteúdo, assim como de uma recusa, mas é também aqui justamente que se verifica a palavra de Lotze a propósito da oposição entre "extensão universal sem exceção" e a "subordinação da significação" que o mecanismo deve realizar na edificação do mundo. No fenômeno completo da consciência, no sentido de "ter consciência de algo", assim como em todos os fenômenos autenticamente patológicos, não somente o sujeito possuidor, o objeto possuído e o modo de posse entram em consideração, mas também a reflexividade deste todo sobre eu mesmo, sua relação ao eu ou com o eu. Na expressão da apercepção de Leibniz, na expressão da reflexão (particularmente a de Locke), há algo que supera o simples "vir à consciência” e, no entanto, esta reflexividade não está aí contida. A reflexão significa, antes, um reflexo da consciência ou do espírito retrovisto em si mesmo, do que um retorno de eu mesmo para eu mesmo. As coisas aparecem como completamente diferentes em uma expressão da língua grega que designa a consciência, expressão que, infelizmente, ao lado de uma outra, bem menos adequada, não se impôs, ficando limitada à consciência moral; é o $\pi \alpha \rho \alpha \chi o \lambda o v \theta \varepsilon \imath v$ ou $\pi \alpha \rho \alpha \chi 0 \lambda \mathrm{ov} \theta \eta \sigma \iota \zeta$ (= seguir como companhia, acompanhamento); quero dizer a syneidesis, o $\sigma v v \varepsilon ı \varepsilon \varepsilon v \alpha \iota$ ou a confiança que tão freqüentemente encontramos como $\sigma v v \varepsilon 1 \delta \varepsilon v \alpha \iota \varepsilon \alpha v \tau \omega$, como "confiança consigo mesmo". Não estou plenamente consciente de uma coisa senão na consciência de algo comigo mesmo; as expressões: menos consciente, subconsciente e, finalmente, inconsciente referem-se unicamente a modos diferenciados do ser em si mesmo ou consigo mesmo, cuja forma inferior é a "corporal” (no sentido aqui da corporeidade e não do corpo anátomo-fisiológico!). Se um conteúdo não estivesse, de uma maneira ou de outra, "em” nossa corporeidade, ou seja, em não importa que membro parcial desta, e se ela não fosse uma forma escondida de nosso próprio ser, jamais poderíamos nos lembrar de um nome "esquecido", tornar "consciente" uma emoção inconsciente, revelar em nós qualquer efeito a partir de algo inconsciente. (Devemos naturalmente dizer o contrário, que não poderíamos esquecer algo, se não pudéssemos existir na corporeidade. Um ser pensado sem nada de corporal - Deus - não pode esquecer!) A psicoterapia em sua forma e função mais próprias, ou seja, que suscitam e educam a comunicação, mostra sempre o médico em um papel propriamente espiritual de mediador entre o doente e o mundo, o mundo comunitário e o mundo ambiente, o que, corretamente compreendido, nunca pode 
querer dizer algo que não seja uma mediação entre o doente como não si mesmo e o doente como si mesmo; pois o caminho para si mesmo sempre passa pelo mundo, assim como o caminho do mundo para o mundo passa por si mesmo. Qualquer psicoterapia bem compreendida é reconciliação do homem consigo mesmo e, portanto, com o mundo, ela é metamorfose da hostilidade em relação a si mesmo em amizade consigo mesmo e, portanto, com o mundo.

É somente a partir deste papel de mediador que as duas formas capitais da psicoterapia deixam-se descrever e enfrentar-se, a saber, a elucidação existencial e a formação em conexão com a pesquisa biográfica e a sugestão. No que diz respeito a esta última, ela foi retomada por Erwin Straus em seus trabalhos sobre a sugestão tão clara e minuciosamente (e, justamente, também na perspectiva do papel do sugestionador considerado como aquele que dissimula o mundo para o "parceiro" e o impede de amadurecer) que apenas podemos aconselhar vivamente ao leitor que se remeta a esses trabalhos arjas concepp̧ões não se separam das nossas senão de maneira acessória.

O caminho que definimos aqui representa o contrário da sugestão: é o caminho que pode ser descrito, inversamente à relação de sugestão, como passando pela relação de amizade, por uma relação que começa pela "emoção espiritual" (no sentido da atitude fundamental da relação humana recíproca que P. Häberlin opõe à sugestão em seu livro sobre este assunto), e que termina na commidade de livre formação au alltura, da coirmnia eleugeraz paideiaz de que Platão fala em sua VII carta.

Fintre estes dbis extremos, há receitas, ritos e preceitos provenientes da psicoterapia, regras ou diretivas para os modos de comportamento psíquicos ou os exercícios pelos quais o próprio psicoterapenta coloca-se completamente em segundo plano quando não quer aparecer como sugestionador e que o serviço prestado ao paciente ocupa a boca da cena, engessado em formas e fórmulas abjetivamente estabelecidas. Fundando-se em nossa representação, o leitor compreenderá que modos de relação puramente corporais e exercícios estimulantes no plano psíquico podem agir e como o fazem; em primeiro lugar, colocamos o trabalho físico (em cujo cômputo deve ser também considerado na primeira linha o fator commitário!) e, adiante, colocamos, por exemplo, a liberação de atitudes conporais e movimentos "contraídos" graças à dança e a uma ginástica apropriada e ao treino metódico, seja por suas formas que descontraem e relaxam, ativas ou passivas, seguindo o que fala Schultz, pois o que você faz como "eu, conpo vivido" e como o faz, sempre dá indicações sobre o eu-alma, sobre você vígil au sobre o homem-em-troca-espiritual-consigo-mesmo.

O leitor, no entanto, não deve achar, ao contrário, que o grande continente das síndrames de inibição, dosessão e angústia não tenha, também ele, suas formas de expressão "conporais", não importa o nome que lhe seja dado. O que, na histe- 
ria, salta tão claramente aos olhos, em virtude da ênfase e da fixação da linguagem conporal, de forma alguma desaparece com as síndromes; o bloqueio psíquico sempre indica alguma fixação na conporeidade; a dbrigação psíquica significa sempre uma estase espaço-temporal e uma perturbação desta, sem falar das neuroses de angústia em que a esfera conporal está justamente em plena efervescência.

Para concluirr, é preciso ainda fazer com que o leitor preste atenção ao que Ihe mostramos: a realidade da ação psicoterapêutica - (a possibilidade que você tem é sempre uma única e mesma passibilidade) - apenas à medida que ela se serve da retomada em mãos de si mesmo a partir da consciência do corpo vivido e de sua linguagem e isto scmente sobre um fragmento deste domínio. Um outro, que é enorme, e que supera de longe o do sonho, é o domínio da consciência e da linguagem imagética. Em princípio, a psicoterapia, aqui, realiza a mesma dora e age exatamente como em nossa doente, pois a esfera conporal e a esfera metafórica estão estreitamente ligadas. Também aqui, o si mesmo deve livrar-se de redes e armadi lhas das imagens nas quais está preso, nas quais ele ainda vive de uma certa maneira, assim como vive de uma certa maneira na esfera conporal. Ao se ocupar do que chama "inconsciente coletivo" (Jung), desliza-se docemente da psicologia para a mitologia porque, aqui, se toma, em primeiro lugar, as imagens como expressão da consciência do gênero humano e não como expressão da consciência humana de si mesmo. Na psicoterapia, exceção feita a diversas fontes de erros possíveis, pareceu-nos, como tradutor, ser importante saber se esta a aquela imagem era intenpretada segunob círoulos de altura diferentes, oriental au "pré-histórica", mas este conhecimento aparece-nos como desvalorizado já que justamente não o considero e não o compreendo como mito deste ou daquele indivíduo e como imagem verbal de sta biografia.

Indicaremos ainda ao leitor, de forma muito genérica, que em nossos doentes a linguagem metafórica apresenta principalmente três formas: as imagens corporais, as imagens psíquicas e as imagens cósmicas (subterrâneas ou supraterrestres).

Permita-nos o leitor acabar de lhe mostrar, em um simples exemplo a propósito de uma outra doente, como estas linguagens não somente se tocam, mas ainda se movem "paralelamente" à linguagem do corpo e da alma, nela e com ela, em reciprocidade. Em um procedimento existencial comunicativo, a doente "abre-se", já que quer comunicar a si mesma e ao médico algo novo até então recalcado, ela experimenta isso fisicamente por um relaxamento do tônus de sua musculatura esfincteriana, por uma metáfora corporal de gravidez e de nascimento de uma criança ou da imagem de um melão (que ele mesmo se abre em dois, por uma metáfora psíquica como uma "aproximação" de uma inspiração ou de uma lembrança emergente da "profundeza” de sua alma como uma fissura estreitamente ligada à idéia recalcada), uma fissura ao rés da rua asfaltada, por uma metáfora cósmica como uma lenta elevação de pesados, gigantescos discos de metal que recobrem toda a 
terra! Inversamente, quando a doente em questão aqui teve a principal experiência vivida em sua infância, que foi em seguida recalcada, quando ela começou a se fechar para o mundo, para o semelhante e para si mesma de modo que uma longa análise foi necessária para que ela se abrisse novamente para o mundo e para a vida, ela experimentou fisicamente um espasmo de sua musculatura esfincteriana que se prolongou até agora, corporalmente expressa no plano metafórico pelas duas metades do melão ou de qualquer outra fruta que se fecha, psiquicamente expressa por um "desaparecimento" de seus pensamentos e de suas lembranças, um endurecimento psíquico e uma devastação, simbolicamente por uma reptação de fantasmas sobre o rés asfaltado de uma rua; no plano cósmico, pela fratura da abóbada celeste em enormes e pesados discos metálicos isolados, nos quais eram dispostas aberturas para as estrelas, a lenta queda destes discos recobrindo a terra e, assim, o esmagamento e a esterilização de toda a superfície da terra; e, em último lugar, em uma metáfora ao mesmo tempo corporal, psíquica e cósmica, a doente avança sobre os discos dispersos como um fantasma de esqueleto que traz, em lugar do coração, uma minúscula fruta vermelho-fogo. Aqui, em nenhum momento se trata de imagens oníricas, mas de imagens aparecidas ou evocadas pela lembrança, durante o trabalho de elucidação da história da vida íntima. Assim como, em nosso exemplo principal, a doente teve, antes de tudo, de ser reconduzida para si mesma a partir de seu eu corporal; aqui, nossa paciente teve, primeiramente, de ser reconduzida a partir das múltiplas formas de seu eu-imagem (eu metafórico) e de seus "mundos", para seu eu corporal, seu eu-corpo vivido, ou seja, para a forma até então completamente "recalcada" da existência física (da existência "em seu corpo", a fim de voltar inicialmente, a partir desta forma, "a si mesma”). O leitor compreenderá que, para o médico, este trabalho de desvelamento e revelação durante anos, terá representado o levantamento difícil e penoso de enormes e pesados discos de metal e sua posterior reunião em uma nova abóbada celeste; pois o que, na realidade, fazemos, em tal trabalho, não é feito finalmente senão por meio de imagens que nos possibilitam experimentá-lo e enunciá-lo. 